\title{
On new ternary hafnium aluminides containing palladium, platinum and gold
}

\author{
Yuriy VERBOVYTSKYY ${ }^{1,2 *}$, Kazimierz ŁĄTKA ${ }^{2}$ \\ ${ }^{1}$ Departamento de Química, Instituto Tecnológico e Nuclear/CFMC-UL, \\ Estrada Nacional 10, P-2686-953, Sacavém Codex, Portugal \\ ${ }^{2}$ M. Smoluchowski Institute of Physics, Jagiellonian University, Reymonta 4, 30-059 Kraków, Poland \\ * Corresponding author. Tel.: +351-21-9946184; fax: +351-21-9941455; e-mail: yuryvv@bigmir.net
}

Received November 4, 2011; accepted June 27, 2012; available on-line November 5, 2012

Six new ternary aluminides, $\mathrm{HfAu}_{0.61} \mathrm{Al}_{1.39}, \mathrm{HfAu}_{0.84} \mathrm{Al}_{1.16}, \mathrm{HfAu}_{1.18} \mathrm{Al}_{0.82}, \mathrm{Hf}_{1.31} \mathrm{Pt}_{4} \mathrm{Al}_{10.13}, \mathrm{Hf}_{6} \mathrm{Pt}_{1.42} \mathrm{Al}_{5.58}$, and $\mathrm{Hf}_{6} \mathbf{P d}_{1.37} \mathrm{Al}_{5.63}$, and a previously reported one, $\mathrm{Hf}_{5} \mathrm{Ni}_{4} \mathrm{Al}$, were prepared by arc-melting. Their crystal structures were studied by $\mathrm{X}$-ray powder diffraction. The above mentioned intermetallics crystallize in the $\mathrm{MgNi}_{2}, \mathrm{MgZn}_{2}, \mathrm{Fe}_{2} \mathrm{P}, \mathrm{Sc}_{1.2} \mathrm{FeSi}_{9.8}, \mathrm{~W}_{6} \mathrm{Fe}_{7}$, and $\mathrm{Zr}_{5} \mathrm{Ni}_{4} \mathrm{Al}$ structure types, respectively. The coordination environment and interactions of the atoms in the investigated compounds are briefly discussed.

\section{Hafnium / Ternary aluminides / X-ray diffraction / Crystal structure}

\section{Introduction}

Numerous intermetallic compounds and alloys (magnetic materials, superconductors, hydrogen storage alloys, etc.) are already being used in many branches of science and technology. Among them, transition metal aluminides have attracted special attention due to their high-temperature resistance, good resistance to rupture and creep at high temperatures, high melting points, good corrosion and oxidation resistance, and low densities. Complex investigations of phase equilibria, crystal structures and physical properties of the phases in such alloy systems are consequently of great importance.

The present work is a continuation of our investigation on the interactions between the components in the $\{\mathrm{Ti}, \mathrm{Zr}, \mathrm{Hf}\}-\{\mathrm{Ag}, \mathrm{Au}, \mathrm{Pd}, \mathrm{Pt}\}-\mathrm{Al}$ systems. To the best of our knowledge, there are 13 ternary hafnium aluminides with concentration $\geq 50$ at.\% Hf known from literature, namely HfAg ${ }_{0.28-0.43} \mathrm{Al}_{1.72-1.57} \quad\left(\mathrm{MgCu}_{2}\right.$-type $) \quad$ [1], $\mathrm{Hf}_{6} \mathrm{Ag}_{0.39-1.43} \mathrm{Al}_{6.61-5.57} \quad\left(\mathrm{~W}_{6} \mathrm{Fe}_{7}\right.$-type $) \quad[1,2]$, $\mathrm{HfAu}_{0.47} \mathrm{Al}_{2.53} \quad\left(\mathrm{AuCu}_{3}\right.$-type $) \quad[3], \quad \mathrm{Hf}_{3} \mathrm{Au}_{2} \mathrm{Al}$ ( $\mathrm{Ti}_{2} \mathrm{Ni}$-type) [4], $\mathrm{HfAu}_{2} \mathrm{Al} \quad\left(\mathrm{BiF}_{3}\right.$-type $)$ [5], $\mathrm{HfPd}_{0.33-1.03} \mathrm{Al}_{1.67-0.97}\left(\mathrm{MgZn}_{2}\right.$-type $)$ [6], $\mathrm{HfPd}_{0.33} \mathrm{Al}_{1.67}$ ( $\mathrm{MgNi}_{2}$-type) [3], $\mathrm{Hf}_{6} \mathrm{Pd}_{7} \mathrm{Al}_{16} \quad\left(\mathrm{Th}_{6} \mathrm{Mn}_{23}\right.$-type $)$ [7], $\mathrm{HfPd}_{2} \mathrm{Al}\left(\mathrm{BiF}_{3}\right.$-type) [8], $\mathrm{HfPt}_{0.36} \mathrm{Al}_{1.64}\left(\mathrm{MgNi}_{2}\right.$-type) [3], HfPtAl (HfRhSn-type) [9], $\mathrm{Hf}_{6} \mathrm{Pt}_{7} \mathrm{Al}_{16}$ $\left(\mathrm{Th}_{6} \mathrm{Mn}_{23}\right.$-type) [7], $\mathrm{HfPt}_{2} \mathrm{Al}$ ( $\mathrm{Na}_{3}$ As-type) [10]. Herein, we present crystal structure determinations of new Hf-based aluminides.

\section{Experimental}

The starting materials for the preparation of the alloys were ingots, all with purities better than 99.95 wt.\%. The samples were prepared directly from the elements by arc-melting the buttons under an argon atmosphere on a water-cooled copper hearth. The products were turned over and remelted at least three times in order to ensure homogeneity. Finally fragments of the alloys were sealed in evacuated quartz tubes and annealed at $600^{\circ} \mathrm{C}$ and $/$ or $800^{\circ} \mathrm{C}$. After the heat treatment, the samples were quenched by submerging the silica tubes in cold water.

$\mathrm{X}$-ray phase and structural analyses were performed using Siemens D500, HZG-4a or PANalytical X'Pert Pro diffractometers ( $\mathrm{Cu} K \alpha$ radiation). The scans were taken in the $\theta / 2 \theta$ mode within the $2 \theta$ region $15-120^{\circ}$ (step scan $0.03-0.05^{\circ}$; counting time per step $15-25 \mathrm{~s}$ ). Theoretical powder patterns were calculated with the help of the PowderCell program [11] and used for the identification of the synthesized phases. The lattice parameters were refined by least-squares fitting using the Latcon program [12]. The FullProf program [13] was used for the Rietveld refinements. A pseudo-Voigt profile shape function was assumed. The background was refined with a polynomial function. Details of the refinements are given in Table 1. 
Yu. Verbovytskyy, K. Łatka, On new ternary hafnium aluminides containing palladium, platinum and gold

Table 1 Parameters for the data collection and structural refinement of the ternary compounds.

\begin{tabular}{|c|c|c|c|c|c|c|c|}
\hline Phase & $\mathrm{HfAu}_{0.61} \mathrm{Al}_{1.39}$ & $\mathrm{HfAu}_{0.84} \mathrm{Al}_{1.16}$ & $\mathrm{HfAu}_{1.18} \mathrm{Al}_{0.82}$ & $\mathrm{Hf}_{1.31} \mathrm{Pt}_{4} \mathrm{Al}_{10.13}$ & $\mathrm{Hf}_{6} \mathrm{Pt}_{1.42} \mathrm{Al}_{5.58}$ & $\mathrm{Hf}_{6} \mathrm{Pd}_{1.37} \mathrm{Al}_{5.63}$ & $\mathrm{Hf}_{5} \mathrm{Ni}_{4} \mathrm{Al}$ \\
\hline $\begin{array}{l}\text { Structure } \\
\text { type }\end{array}$ & $\mathrm{MgNi}_{2}$ & $\mathrm{MgZn}_{2}$ & $\mathrm{Fe}_{2} \mathrm{P}$ & $\mathrm{Sc}_{1.2} \mathrm{Fe}_{4} \mathrm{Si}_{9.8}$ & $\mathrm{~W}_{6} \mathrm{Fe}_{7}$ & $\mathrm{~W}_{6} \mathrm{Fe}_{7}$ & $\mathrm{Zr}_{5} \mathrm{Ni}_{4} \mathrm{Al}$ \\
\hline $\begin{array}{l}\text { Space } \\
\text { group }\end{array}$ & $\mathrm{P6}_{3} / \mathrm{mmc}$ & $P 6_{3} / m m c$ & $P-62 m$ & $P 6_{3} / m m c$ & $R-3 m$ & $R-3 m$ & $P 4_{2} / m$ \\
\hline $\begin{array}{l}\text { Pearson } \\
\text { symbol }\end{array}$ & $h P 24$ & $h P 12$ & $h P 9$ & $h P 20-4.56$ & $h R 39$ & $h R 39$ & $t P 20$ \\
\hline Z & 8 & 4 & 3 & 1 & 3 & 3 & 2 \\
\hline $\begin{array}{l}\text { Lattice } \\
\text { parameters }\end{array}$ & & & & & & & \\
\hline$a, \AA$ & $5.27617(7)$ & $5.29923(8)$ & $6.76709(15)$ & $4.24230(12)$ & $5.2998(3)$ & $5.3047(2)$ & 7.1308(3) \\
\hline$c, \AA$ & 17.1204(3) & $8.50031(16)$ & 4.08806(11) & $16.1521(5)$ & $29.065(2)$ & $29.0416(15)$ & $6.5176(4)$ \\
\hline$V, \AA^{3}$ & $412.744(10)$ & $206.724(6)$ & $162.126(7)$ & $251.771(15)$ & $707.00(8)$ & $707.74(5)$ & $331.41(3)$ \\
\hline $\begin{array}{l}\text { Diffracto- } \\
\text { meter }\end{array}$ & $\begin{array}{l}\text { PANalytical } \\
\text { X'Pert Pro }\end{array}$ & $\begin{array}{l}\text { PANalytical } \\
\text { X'Pert Pro }\end{array}$ & $\begin{array}{l}\text { PANalytical } \\
\text { X'Pert Pro }\end{array}$ & $\begin{array}{l}\text { PANalytical } \\
\text { X'Pert Pro }\end{array}$ & HZG-4a & HZG-4a & $\begin{array}{l}\text { PANalytical } \\
\text { X'Pert Pro }\end{array}$ \\
\hline Radiation & $\mathrm{Cu} K \alpha$ & $\mathrm{Cu} K \alpha$ & $\mathrm{Cu} K \alpha$ & $\mathrm{Cu} K \alpha$ & $\mathrm{Cu} K \alpha$ & $\mathrm{Cu} K \alpha$ & $\mathrm{Cu} K \alpha$ \\
\hline $\begin{array}{l}\text { Data range } \\
2 \theta,^{\circ}\end{array}$ & $15-100$ & $15-100$ & $15-100$ & $20-100$ & $10-145$ & $10-145$ & $15-120$ \\
\hline $\begin{array}{l}\text { Counting } \\
\text { step }\end{array}$ & 0.03 & 0.03 & 0.03 & 0.03 & 0.05 & 0.05 & 0.03 \\
\hline $\begin{array}{l}\text { Counting } \\
\text { time, } \mathrm{s}\end{array}$ & 20 & 20 & 20 & 15 & 25 & 25 & 25 \\
\hline $\begin{array}{l}\text { Number of } \\
\text { reflections }\end{array}$ & 105 & 56 & 51 & 67 & 217 & 217 & 274 \\
\hline $\begin{array}{l}\text { Number of } \\
\text { refined } \\
\text { parameters } \\
\text { Reliability } \\
\text { factors }\end{array}$ & 28 & 23 & 23 & 27 & 27 & 27 & 28 \\
\hline$R_{\mathrm{B}}, \%$ & 6.46 & 8.14 & 8.62 & 5.58 & 6.10 & 6.98 & 6.46 \\
\hline$R_{\mathrm{p}}, \%$ & 7.27 & 6.68 & 8.27 & 8.03 & 2.86 & 2.80 & 6.89 \\
\hline
\end{tabular}

\section{Results and discussion}

The HfAu $A_{x} A l_{2-x}$ phases

The crystal structure transformations of the Laves phases in the $\mathrm{Hf}-\{\mathrm{Cu}, \mathrm{Ag}, \mathrm{Au}\}-\mathrm{Al}$ systems have already been reported $[1,3,14]$. The replacement of $\mathrm{Al}$ atoms in the binary $\mathrm{HfAl}_{2}$ compound by a small amount of $\mathrm{Ag}$ or $\mathrm{Au}$ atoms leads to the following structural transformation: $\mathrm{MgZn}_{2}\left(\mathrm{HfAl}_{2}\right) \rightarrow \mathrm{MgCu}_{2}$ $\left(\mathrm{HfAg}_{0.28-0.43} \mathrm{Al}_{1.72-1.57}\right.$ or $\left.\mathrm{HfAu}_{0.47} \mathrm{Al}_{2.53}\right)$. Recent studies [15] of alloys in the $\mathrm{Hf}-\mathrm{Cu}-\mathrm{Al}$ system revealed a change of the structure type in the sequence $\mathrm{MgZn}_{2}\left(\mathrm{HfAl}_{2}\right) \rightarrow \mathrm{MgCu}_{2}\left(\mathrm{HfCu}_{0.2-0.5} \mathrm{Al}_{1.8-1.5}\right) \rightarrow$ $\mathrm{MgNi}_{2}\left(\mathrm{HfCu}_{0.7-0.9} \mathrm{Al}_{1.3-1.1}\right) \rightarrow \mathrm{MgZn}_{2}$ (HfCuAl). In order to find isostructural phases, studies of as-cast and annealed (at $800^{\circ} \mathrm{C}$ ) $\mathrm{HfAu}_{\mathrm{x}} \mathrm{Al}_{2-\mathrm{x}}$ alloys with $\mathrm{x}=0.6,0.85,1.0$, and 1.2 were performed. X-ray phase analysis of the alloys showed the existence of three new ternary compounds. At the value of $x=0.6$ the pattern exhibits an almost single phase of the $\mathrm{MgNi}_{2}$ structure type (Fig. 1). A mixture of phases with $\mathrm{MgZn}_{2}$ and $\mathrm{Fe}_{2} \mathrm{P}$ structure types was recognized in the $\mathrm{HfAu}_{\mathrm{x}} \mathrm{Al}_{2-\mathrm{x}}$ alloys with $\mathrm{x}=0.85$ and 1.0. For $\mathrm{x}=1.2$ the XRD pattern displayed only one phase with $\mathrm{Fe}_{2} \mathrm{P}$ structure type (Fig. 2). Results of the crystal structure determination can be found in Tables 1 and 2.

Since the crystal and chemical details of Laves phases and $\mathrm{Fe}_{2} \mathrm{P}$-type intermetallics have been widely described, herein we will discuss only briefly the structures of the investigated $\mathrm{HfAu}_{\mathrm{x}} \mathrm{Al}_{2-\mathrm{x}}$ compounds. In the structures of the Laves phases, i.e. $\mathrm{HfAu}_{0.61} \mathrm{Al}_{1.39} \quad\left(\mathrm{MgNi}_{2}\right.$-type $)$ and $\mathrm{HfAu}_{0.84} \mathrm{Al}_{1.16}$ ( $\mathrm{MgZn}_{2}$-type) (Fig. 3), the Hf atoms occupy the positions of the $\mathrm{Mg}$ atoms, while the $\mathrm{Au}$ and $\mathrm{Al}$ atoms form a statistical mixture and are distributed over the $\mathrm{Ni}$ or $\mathrm{Zn}$ sites, respectively. The nearest neighbors of the Hf atoms form 16-vertex Frank-Kasper polyhedra. The $M(\mathrm{Au}$ and $\mathrm{Al})$ atoms are located in icosahedra. The interatomic distances in the structures of the $\mathrm{HfAu}_{0.61} \mathrm{Al}_{1.39}$ and $\mathrm{HfAu}_{0.84} \mathrm{Al}_{1.16}$ phases (given in the supplementary material) are close to the sum of the atomic radii of the respective atoms [16].

The $\mathrm{HfAu}_{1.18} \mathrm{Al}_{0.82}$ phase was found to adopt the $\mathrm{ZrNiAl}\left(\mathrm{Fe}_{2} \mathrm{P}\right)$ structure type (Fig. 4). Here the $\mathrm{Hf}$ atoms occupy the $\mathrm{Zr}$ site; $\mathrm{Au}$ atoms (M1 and $M 2)$ are located in the Ni positions, and $\mathrm{Au}$ and $\mathrm{Al}$ atoms (M3) are situated in the positions of $\mathrm{Al}$. The atoms surrounding the Hf atoms form an equatorially five- 


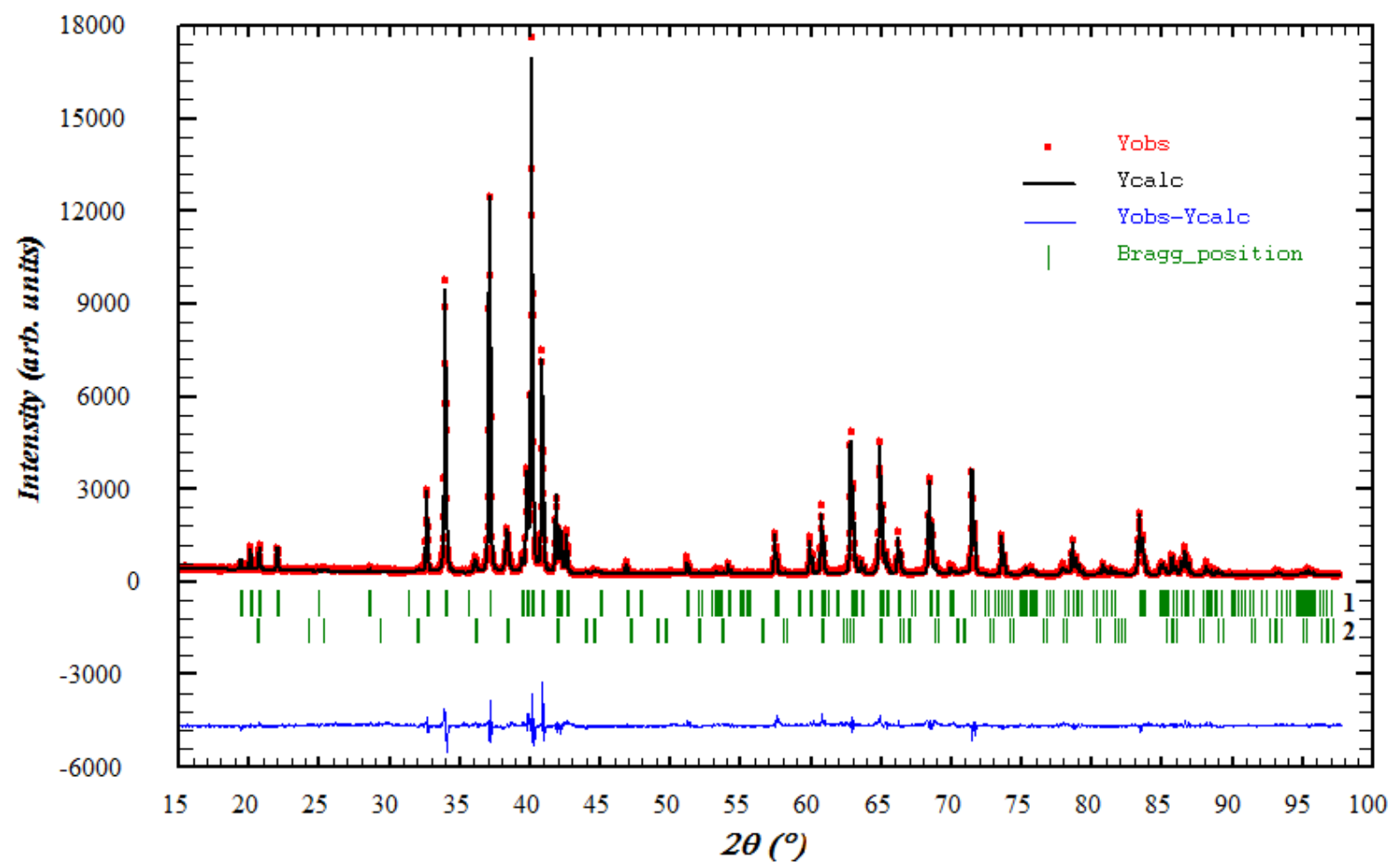

Fig. 1 Rietveld refinement of the sample $\mathrm{Hf}_{33} \mathrm{Au}_{20} \mathrm{Al}_{47}\left(1-\mathrm{HfAu}_{0.61} \mathrm{Al}_{1.39}\right.$ and $\left.2-\mathrm{Hf}_{3} \mathrm{Au}_{2} \mathrm{Al}\right)$ (red circles experimental, black line - theoretical, blue line - difference data, green bars - Bragg positions).

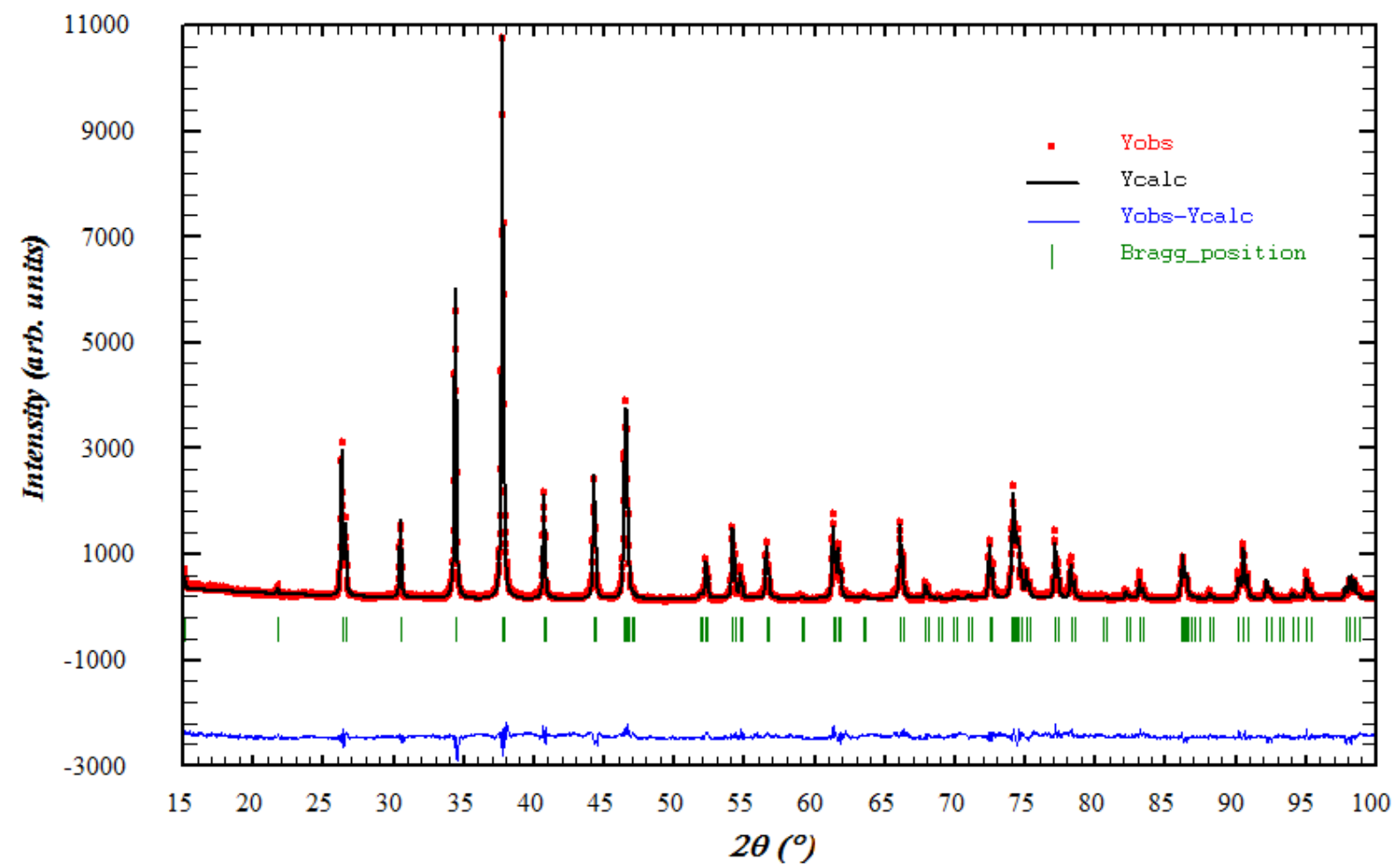

Fig. 2 Rietveld refinement of the sample $\mathrm{Hf}_{33} \mathrm{Au}_{40} \mathrm{Al}_{27}\left(\mathrm{HfAu}_{1.18} \mathrm{Al}_{0.82}\right)$ (red circles - experimental, black line - theoretical, blue line - difference data, green bars - Bragg positions). 


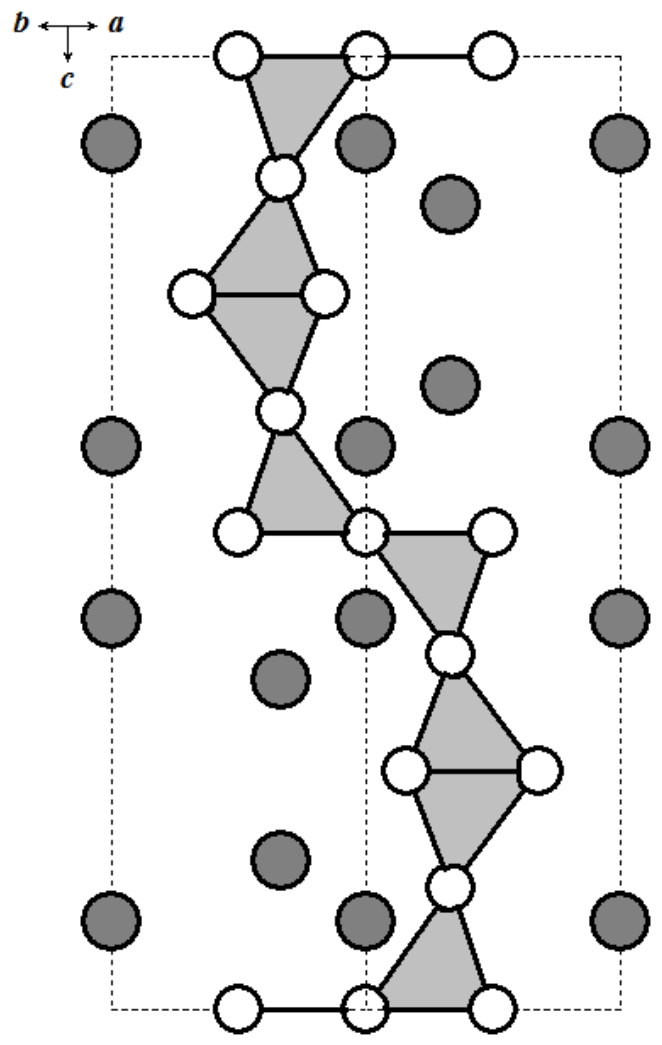

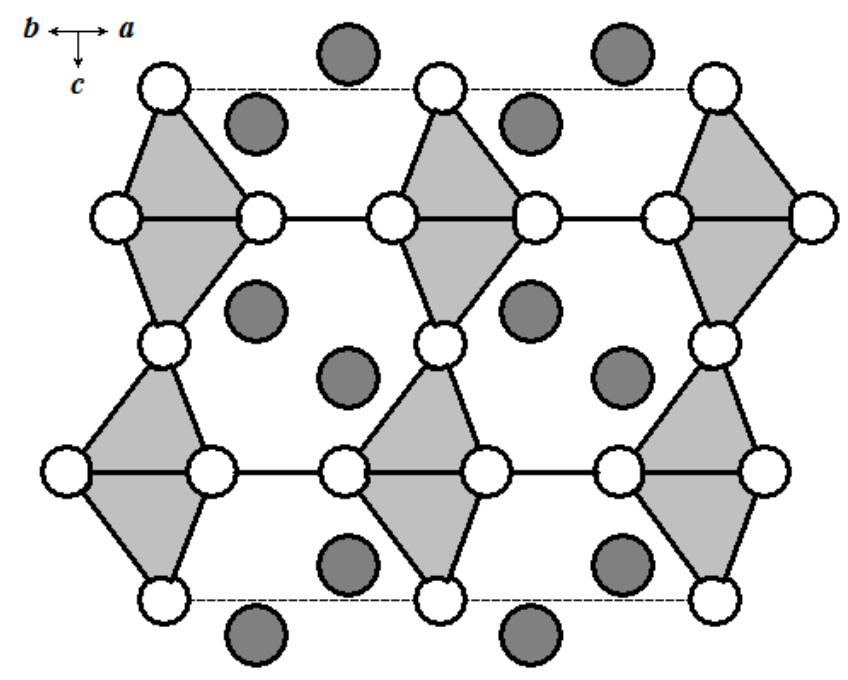

b

Fig. 3 Crystal structures of $\mathrm{HfAu}_{0.61} \mathrm{Al}_{1.39}\left(\mathrm{MgNi}_{2}\right.$-type) (a) and $\mathrm{HfAu}_{0.84} \mathrm{Al}_{1.16}\left(\mathrm{MgZn}_{2}\right.$-type) (b). Dark circles represent $\mathrm{Hf}$ atoms and white ones $M(\mathrm{Au}$ and $\mathrm{Al})$ atoms. Tetrahedrons $\left[M_{4}\right]$ are filled by gray color.

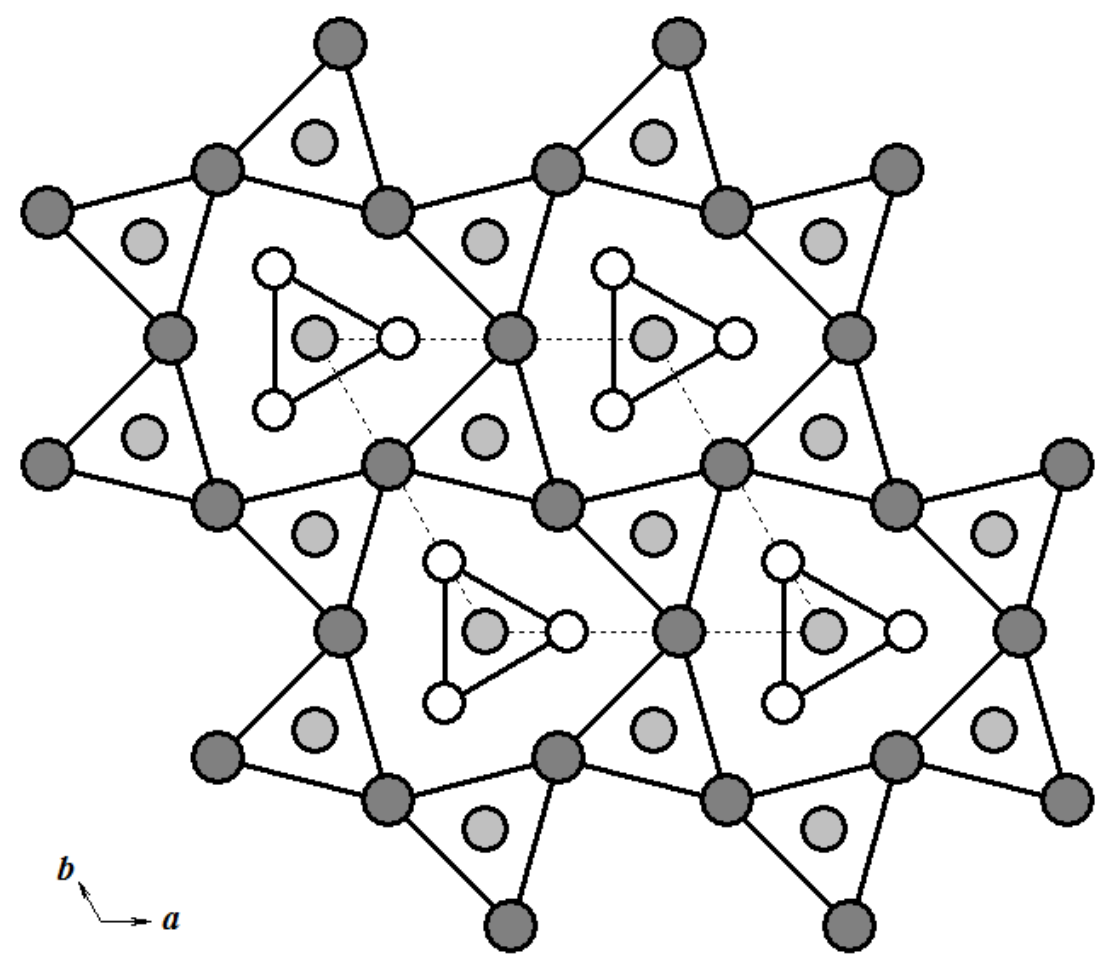

Fig. 4 Projection of the structure of $\mathrm{HfAu}_{1.18} \mathrm{Al}_{0.82}$ onto the $X Y$ plane. Hf atoms are shown as dark gray circles, $\mathrm{Au}$ and $\mathrm{Al}$ as light gray and white ones, respectively. 
capped pentagonal prism. The coordination polyhedra of the $M 1$ and $M 2$ atoms are equatorially tri-capped trigonal prisms. The $M 3$ atoms are located in 12-vertex polyhedra. The values of the interatomic distances (see supplementary material) are in good agreement with the sums of the atomic radii of the respective components [16].

\section{The $\mathrm{Hf}_{1.31} \mathrm{Pt}_{4} A l_{10.13}$ phase}

During the X-ray phase analysis of Al-rich alloys, ascast and annealed at $600^{\circ} \mathrm{C}$, we found the new ternary phase $\mathrm{Hf}_{1.31} \mathrm{Pt}_{4} \mathrm{Al}_{10.13}$ with hexagonal $\mathrm{Sc}_{1.2} \mathrm{Fe}_{4} \mathrm{Si}_{9.8}$ structure type. The crystal structure was investigated on the base of XRD data (Fig. 5). The refined lattice parameters were found to be: $a=4.24230(12) \AA$ and $c=16.1521(5) \AA$. The atomic coordinates are given in Table 2. The Pt, Al1 and Al2 sites are fully occupied. The occupancy parameters of the sites $\mathrm{Hf}$ and $\mathrm{Al} 3$ were found to be equal to $65.4(5) \%$ and $35.5(18) \%$, respectively. They are very close to the values of $2 / 3(66.7 \%)$ and $1 / 3$ $(33.3 \%)$. The positions of the Hf atoms $(2 c)$ are very close to the positions of three Al3 atoms (6h). Moreover, these three Al3 positions are also very close to each other. The refined composition $\mathrm{Hf}_{1.31} \mathrm{Pt}_{4} \mathrm{Al}_{10.13}$ is close to the ideal one, $\mathrm{Hf}_{1.33} \mathrm{Pt}_{4} \mathrm{Al}_{10}$ $\left(2 / 3 \times \mathrm{Hf}_{2} \mathrm{Pt}_{6} \mathrm{Al}_{15}\right)$, indicating the possible existence of an ordered superstructure. Some examples of ordered superstructures of the $\mathrm{Sc}_{1.2} \mathrm{Fe}_{4} \mathrm{Si}_{9.8}$ structure type are discussed in $[17,18]$.

Table 2 Atomic coordinates and displacement parameters of the ternary compounds.

\begin{tabular}{|c|c|c|c|c|c|c|}
\hline Atom & $\begin{array}{l}\text { Wyckoff } \\
\text { position }\end{array}$ & $x$ & $y$ & $z$ & $B_{\text {iso }}, \stackrel{\circ}{ }^{2}$ & Occupation \\
\hline \multicolumn{7}{|c|}{$\mathrm{HfAu}_{0.61} \mathrm{Al}_{1.39}\left(\right.$ space group $\left.P 6_{3} / m m c\right)$} \\
\hline Hf1 & $4 e$ & 0 & 0 & $0.09184(12)$ & $0.73(6)$ & $1 \mathrm{Hf}$ \\
\hline Hf2 & $4 f$ & $1 / 3$ & $2 / 3$ & $0.65555(13)$ & $0.74(6)$ & $1 \mathrm{Hf}$ \\
\hline$M 1$ & $4 f$ & $1 / 3$ & $2 / 3$ & $0.1279(3)$ & $1.26(15)$ & $0.346(5) \mathrm{Au}+0.654(5) \mathrm{Al}$ \\
\hline$M 2$ & $6 g$ & $1 / 3$ & 0 & 0 & $1.32(18)$ & $0.255(6) \mathrm{Au}+0.745(6) \mathrm{Al}$ \\
\hline$M 3$ & $6 h$ & $0.1604(8)$ & $2 x$ & $1 / 4$ & $1.30(16)$ & $0.332(6) \mathrm{Au}+0.668(6) \mathrm{Al}$ \\
\hline \multicolumn{7}{|c|}{$\mathrm{HfAu}_{0.84} \mathrm{Al}_{1.16}\left(\right.$ space group $\left.P 6_{3} / m m c\right)$} \\
\hline Hf & $4 f$ & $1 / 3$ & $2 / 3$ & $0.5670(2)$ & $1.08(6)$ & $1 \mathrm{Hf}$ \\
\hline$M 1$ & $2 a$ & 0 & 0 & 0 & $1.46(17)$ & $0.523(11) \mathrm{Au}+0.477(11) \mathrm{Al}$ \\
\hline$M 2$ & $6 h$ & $0.1743(8)$ & $2 x$ & $1 / 4$ & $1.42(11)$ & $0.383(5) \mathrm{Au}+0.617(5) \mathrm{Al}$ \\
\hline \multicolumn{7}{|c|}{$\mathrm{HfAu}_{1.18} \mathrm{Al}_{0.82}($ space group $P-62 m)$} \\
\hline Hf & $3 f$ & $0.5736(4)$ & 0 & 0 & $0.64(4)$ & $1 \mathrm{Hf}$ \\
\hline$M 1$ & $1 a$ & 0 & 0 & 0 & $1.12(11)$ & $1 \mathrm{Au}$ \\
\hline$M 2$ & $2 d$ & $1 / 3$ & $2 / 3$ & $1 / 2$ & $0.90(7)$ & $1 \mathrm{Au}$ \\
\hline$M 3$ & $3 g$ & $0.2406(14)$ & 0 & $1 / 2$ & $1.0(2)$ & $0.180(10) \mathrm{Au}+0.820(10) \mathrm{Al}$ \\
\hline \multicolumn{7}{|c|}{$\mathrm{Hf}_{1.31} \mathrm{Pt}_{4} \mathrm{Al}_{10.13}$ (space group $\left.P 6_{3} / m m c\right)$} \\
\hline $\mathrm{Hf}$ & $2 c$ & $1 / 3$ & $2 / 3$ & $1 / 4$ & $1.40(10)$ & $0.654(5) \mathrm{Hf}$ \\
\hline $\mathrm{Pt}$ & $4 f$ & $1 / 3$ & $2 / 3$ & $0.60992(6)$ & $0.93(4)$ & $1 \mathrm{Pt}$ \\
\hline Al1 & $4 f$ & $1 / 3$ & $2 / 3$ & $0.0500(4)$ & $0.73(17)$ & $1 \mathrm{Al}$ \\
\hline $\mathrm{A} 12$ & $4 e$ & 0 & 0 & $0.1415(5)$ & $1.13(19)$ & $1 \mathrm{Al}$ \\
\hline $\mathrm{Al} 3$ & $6 h$ & $0.5609(50)$ & $2 x$ & $1 / 4$ & $1.5(4)$ & $0.355(18) \mathrm{Al}$ \\
\hline \multicolumn{7}{|c|}{$\mathrm{Hf}_{6} \mathrm{Pt}_{1.42} \mathrm{Al}_{5.58}($ space group $R-3 m)$} \\
\hline Hf1 & $6 c$ & 0 & 0 & $0.04534(19)$ & $0.83(14)$ & $1 \mathrm{Hf}$ \\
\hline Hf 2 & $6 c$ & 0 & 0 & $0.15129(19)$ & $0.33(13)$ & $1 \mathrm{Hf}$ \\
\hline Hf3 & $6 c$ & 0 & 0 & $0.33475(16)$ & $0.50(13)$ & $1 \mathrm{Hf}$ \\
\hline$M 1$ & $3 b$ & 0 & 0 & $1 / 2$ & $1.5(2)$ & $0.190(15) \mathrm{Pt}+0.810(15) \mathrm{Al}$ \\
\hline$M 2$ & $18 h$ & $0.5017(13)$ & $-x$ & $0.0913(4)$ & $1.5(2)$ & $0.205(7) \mathrm{Pt}+0.795(7) \mathrm{Al}$ \\
\hline \multicolumn{7}{|c|}{$\mathrm{Hf}_{6} \mathrm{Pd}_{1.37} \mathrm{Al}_{5.63}($ space group $R-3 m)$} \\
\hline Hf1 & $6 c$ & 0 & 0 & $0.04555(18)$ & $0.94(12)$ & $1 \mathrm{Hf}$ \\
\hline Hf2 & $6 c$ & 0 & 0 & $0.14999(17)$ & $0.37(11)$ & $1 \mathrm{Hf}$ \\
\hline Hf3 & $6 c$ & 0 & 0 & $0.33396(15)$ & $0.78(12)$ & $1 \mathrm{Hf}$ \\
\hline$M 1$ & $3 b$ & 0 & 0 & $1 / 2$ & $1.1(2)$ & $0.200(22) \mathrm{Pd}+0.800(22) \mathrm{Al}$ \\
\hline$M 2$ & $18 h$ & $0.5013(14)$ & $-x$ & $0.0924(5)$ & $1.1(2)$ & $0.196(10) \mathrm{Pd}+0.804(10) \mathrm{Al}$ \\
\hline \multicolumn{7}{|c|}{$\mathrm{Hf}_{5} \mathrm{Ni}_{4} \mathrm{Al}$ (space group $\mathrm{P}_{2} / m$ ) } \\
\hline Hf1 & $2 e$ & 0 & 0 & $1 / 4$ & $1.04(10)$ & $1 \mathrm{Hf}$ \\
\hline Hf2 & $4 j$ & $0.1840(12)$ & $0.3495(18)$ & 0 & $0.7(3)$ & $1 \mathrm{Hf}$ \\
\hline Hf3 & $4 j$ & $0.6419(18)$ & $0.1876(12)$ & 0 & $1.2(3)$ & $1 \mathrm{Hf}$ \\
\hline $\mathrm{Ni}$ & $8 k$ & $0.8746(8)$ & $0.3639(8)$ & $0.2448(34)$ & $1.28(15)$ & $1 \mathrm{Ni}$ \\
\hline $\mathrm{Al}$ & $2 f$ & $1 / 2$ & $1 / 2$ & $1 / 4$ & $1.0(5)$ & $1 \mathrm{Al}$ \\
\hline
\end{tabular}




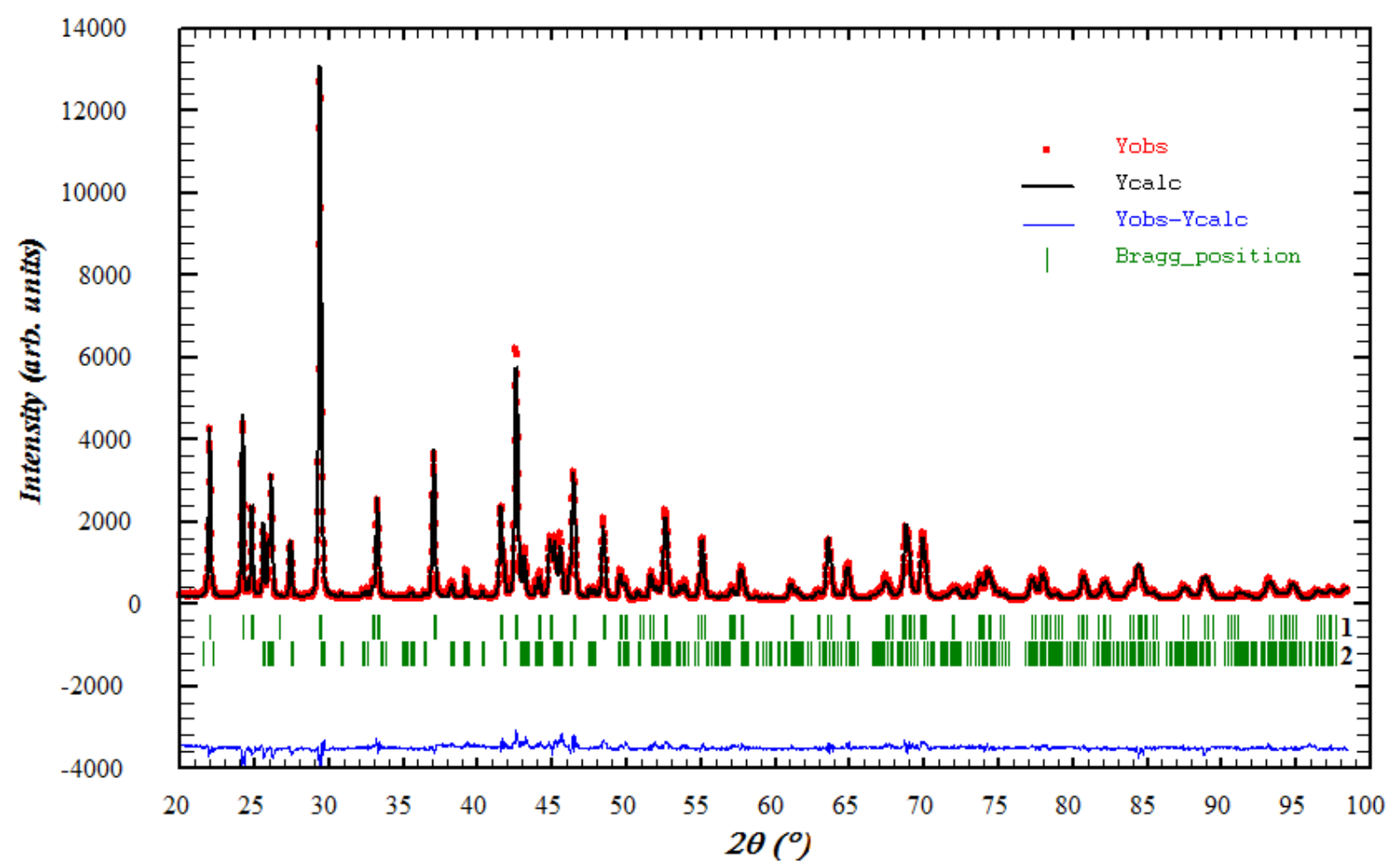

Fig. 5 Rietveld refinement of the sample $\mathrm{Hf}_{7} \mathrm{Pt}_{26} \mathrm{Al}_{67}\left(1-\mathrm{Hf}_{1.31} \mathrm{Pt}_{4} \mathrm{Al}_{10.13}\right.$ and $2-\mathrm{Pt}_{8} \mathrm{Al}_{21}$ ) (red circles experimental, black line - theoretical and blue line - difference data, green bars - Bragg positions).

The unit cell of $\mathrm{Hf}_{1.31} \mathrm{Pt}_{4} \mathrm{Al}_{10.13}$ is shown in Fig. 6 . Interatomic distances and coordination numbers of the atoms are given in the supplementary material. The coordination polyhedra of the Hf atoms (assuming local order) are formed by six $\mathrm{Pt}$ and eleven $\mathrm{Al}$ atoms. The Pt atoms are surrounded by eight $\mathrm{Al}$ and two $\mathrm{Hf}$ atoms. The neighbors (6Al, $4 \mathrm{Pt}$ and $1 \mathrm{Hf}$ ) of the Al1 atoms form 11-vertex polyhedra. The coordination spheres of the $\mathrm{Al} 2$ and $\mathrm{Al} 3$ atoms are constructed by ten neighbors $\left(\mathrm{Hf}_{2} \mathrm{Pt}_{3} \mathrm{Al}_{5}\right.$ or $\mathrm{HfPt}_{3} \mathrm{Al}_{6}$, and $\mathrm{Hf}_{2} \mathrm{Pt}_{2} \mathrm{Al}_{6}$, respectively). The $\mathrm{Hf}-\mathrm{Al}$ distances vary between 2.917 and $3.230 \AA$, which is close to the sum of the atomic radii of $\mathrm{Hf}$ and $\mathrm{Al}(3.02 \AA)$ [16]. The distances between the $\mathrm{Hf}$ and Pt atoms (3.334 $\AA$ ) are somewhat longer than the sum $(2.96 \AA)$ of the atomic radii. The Pt-Al distances range from 2.392 to $2.634 \AA$, indicating strong interactions between these atoms. For comparison, the corresponding sum for $\mathrm{Pt}$ and $\mathrm{Al}$ atoms in the pure metals is $2.80 \AA$ [16]. The Al-Al contacts (2.861-2.934 $\AA$ ) are close to the interatomic distances in elementary aluminum.

\section{The $H_{6} P t_{1.42} A l_{5.58}$ and $H f_{6} P d_{1.37} A l_{5.63}$ phases}

In the alloys with compositions along the crosssection with 46.2 at.\% hafnium (as-cast or annealed at $600^{\circ} \mathrm{C}$ or $800^{\circ} \mathrm{C}$ ) two new ternary compounds, $\mathrm{Hf}_{6} \mathrm{Pt}_{1.42} \mathrm{Al}_{5.58}$ and $\mathrm{Hf}_{6} \mathrm{Pd}_{1.37} \mathrm{Al}_{5.63}$, were found. The indexation of the conventional X-ray powder diffraction data with a rhombohedral unit cell
(Table 1), the cla ratio and intensities of the peaks indicated that the structure type of the above mentioned phases is $\mathrm{W}_{6} \mathrm{Fe}_{7}$. The refinement on X-ray powder diffraction data, using the Rietveld method, confirmed our prediction, with reliability factors of $R_{\mathrm{B}}=6.10 \%$ and $R_{\mathrm{B}}=6.98 \%$, respectively. The atomic coordinates and displacement parameters are presented in Table 2. The Hf atoms occupy the positions of the $\mathrm{W}$ atoms, while the $\mathrm{Pt}(\mathrm{Pd})$ and $\mathrm{Al}$ atoms are statistically distributed over the positions of the $\mathrm{Fe}$ atoms in the structure of $\mathrm{W}_{6} \mathrm{Fe}_{7}$.

A projection of the structure along the $c$-axis and the coordination polyhedra of the atoms are shown in Fig. 7. The Hf atoms are located inside 14-, 15- and 16-vertex Frank-Kasper polyhedra. The coordination polyhedra of the statistical mixture $M(\mathrm{Pt} / \mathrm{Al}$ and $\mathrm{Pd} / \mathrm{Al}$ ) are icosahedra. A more detailed crystal chemical analysis of phases with the $\mathrm{W}_{6} \mathrm{Fe}_{7}$ structure type in the $\{\mathrm{Zr}, \mathrm{Hf}, \mathrm{Nb}, \mathrm{Ta}\}-d$-metal-Al systems is given in [19]. Calculated interatomic distances in the structure of $\mathrm{Hf}_{6} \mathrm{Pt}_{1.42} \mathrm{Al}_{5.58}$ and $\mathrm{Hf}_{6} \mathrm{Pd}_{1.37} \mathrm{Al}_{5.63}$ can be found in the supplementary material. The Hf-Hf contacts vary over a wide range, however, significantly shorter distances $(\sim 2.64 \AA)$ are formed between Hf1 atoms. Similar interactions between transition atoms occur also in structures with the $\mathrm{Zr}_{4} \mathrm{Al}_{3}$ - and $\mathrm{Nb}_{2} \mathrm{Al}$-types [20]. The Hf- $M$ distances are close to the sums of the atomic radii [16], indicating weak interactions. The $M-M$ distances extend between 2.623 and $2.681 \AA\left(\mathrm{Hf}_{6} \mathrm{Pt}_{1.42} \mathrm{Al}_{5.58}\right)$, or 2.632 and $2.673 \AA\left(\mathrm{Hf}_{6} \mathrm{Pd}_{1.37} \mathrm{Al}_{5.63}\right)$, being considerably shorter 


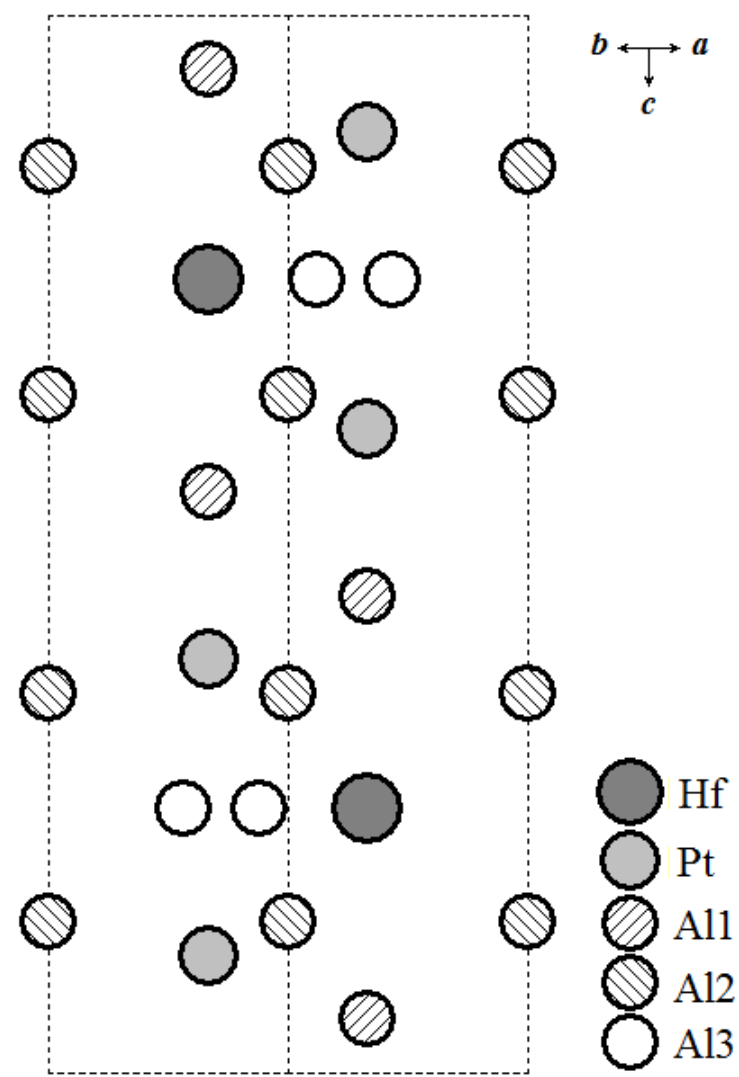

Fig. 6 Crystal structure of $\mathrm{Hf}_{1.31} \mathrm{Pt}_{4} \mathrm{Al}_{10.13}$.

than the sum $(2.84 \AA)$ of radii of the respective elements $\left(2 r_{M} \sim 2 r_{\mathrm{Al}} \sim 2.86 \AA\right)$ [16], thus pointing to strong $M-M$ bonding.

\section{The $\mathrm{Hf}_{5} \mathrm{Ni}_{4} \mathrm{Al}$ phase}

The Hf-Ni-Al system is well-known as a glassforming system, but detailed features are still under investigation. The first isothermal section (at $800^{\circ} \mathrm{C}$ ) of the phase diagram was published by Markiv et al. [21]. According to [20], at least ten ternary phases have been reported in this system and the structures of $\mathrm{Hf}_{4} \mathrm{Ni}_{16} \mathrm{Al}_{5}$ and $\mathrm{Hf}_{5} \mathrm{Ni}_{4} \mathrm{Al}$ were not determined. We have confirmed the existence of $\mathrm{Hf}_{5} \mathrm{Ni}_{4} \mathrm{Al}$ in as-cast alloys and alloys annealed at $800^{\circ} \mathrm{C}$. Comparing the XRD data of $\mathrm{Hf}_{5} \mathrm{Ni}_{4} \mathrm{Al}$ with known structures, we focused our attention on the previously reported $\mathrm{Zr}_{5} \mathrm{Ni}_{4} \mathrm{Al}$ type [22]. The crystal structure refinement (see Tables 1 and 2) resulted in a low residual factor $\left(R_{\mathrm{B}}=6.46 \%\right)$, confirming the choice of the model.

The unit cell content and the coordination polyhedra of the atoms in the structure of $\mathrm{Hf}_{5} \mathrm{Ni}_{4} \mathrm{Al}$ are presented in Fig. 8. The coordinations of the atoms are very similar to those observed for other compounds with the $\mathrm{Zr}_{3} \mathrm{Al}_{2}$ and $\mathrm{U}_{3} \mathrm{Si}_{2}$ structure types. The coordination polyhedra (full-capped deformed cube) of the Hf1 atoms are formed by $4 \mathrm{Ni}$ and $10 \mathrm{Hf}$ atoms. The Hf1 and Hf2 atoms are located inside tri-capped deformed pentagonal prisms, $\left[\mathrm{Hf}_{5} \mathrm{Ni}_{6} \mathrm{Al}_{2}\right]$. Equatorially tri-capped deformed trigonal prisms are

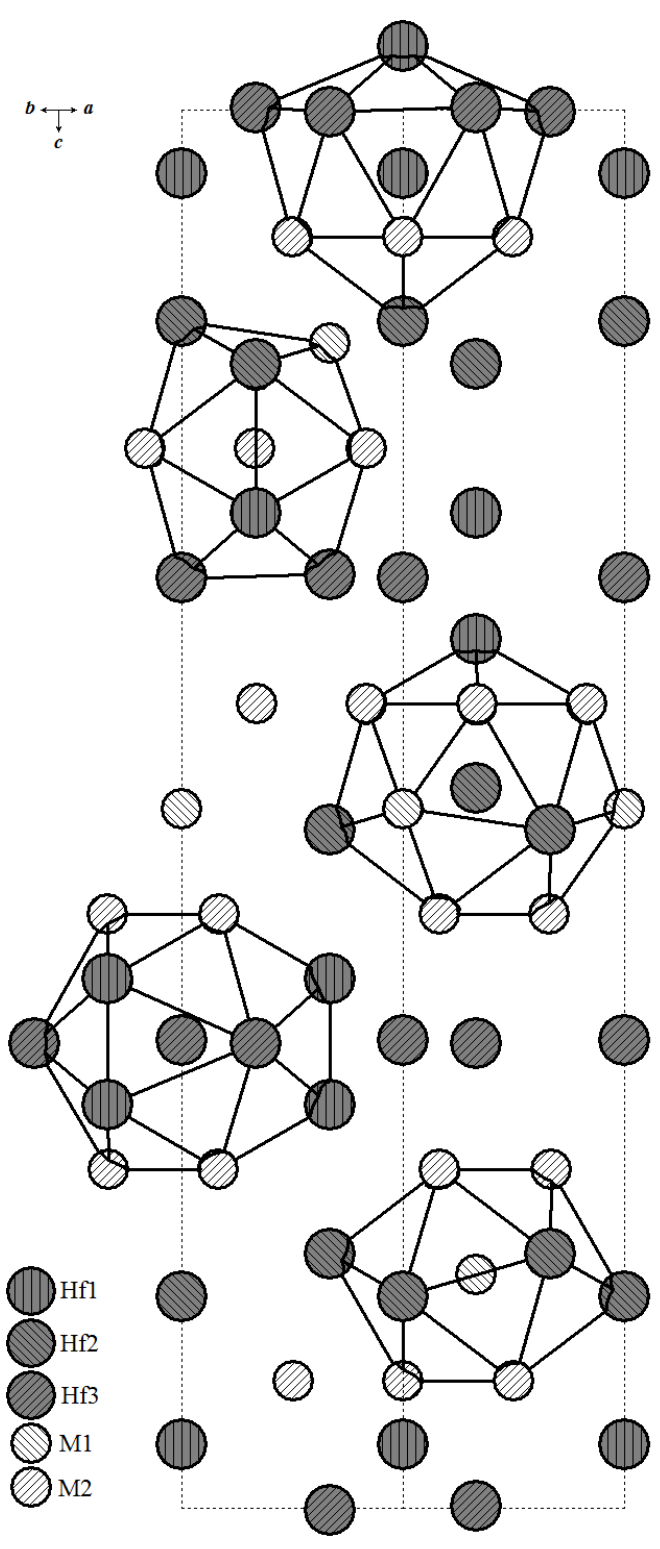

Fig. 7 Unit cell and coordination polyhedra of the atoms in the structures of $\mathrm{Hf}_{6} \mathrm{Pt}_{1.42} \mathrm{Al}_{5.58}$ and $\mathrm{Hf}_{6} \mathrm{Pd}_{1.37} \mathrm{Al}_{5.63}$.

the coordination polyhedra of the $\mathrm{Ni}$ atoms. The neighbors of the $\mathrm{Al}$ atoms form capped deformed cubes, $\left[\mathrm{Hf}_{8} \mathrm{Ni}_{4} \mathrm{Al}_{2}\right]$. Interatomic distances are given in the supplementary material. The Hf-Hf contacts (3.254-3.390 $\AA$ ) are somewhat longer than the distance $3.18 \AA$ in pure hafnium metal [16]. The Hf-Ni (2.626-2.784 $\AA$ ) and Hf-Al (2.940$2.981 \AA$ ) distances are close to the sum of $r_{\mathrm{Hf}}+r_{\mathrm{Ni}}(2.83 \AA)$ and $r_{\mathrm{Hf}}+r_{\mathrm{Al}}(3.02 \AA)$, respectively. Very weak interactions were observed for $\mathrm{Ni}-\mathrm{Ni}$, $\mathrm{Ni}-\mathrm{Al}$ and $\mathrm{Al}-\mathrm{Al}$ atoms. The corresponding interatomic distances were found to be 2.639, 2.842 and $3.259 \AA$, respectively. For comparison, the sum of the radii of the respective elements are 3.48 $\left(2 r_{\mathrm{Ni}}\right), 2.67\left(r_{\mathrm{Ni}}+r_{\mathrm{Al}}\right)$ and $2.86 \AA\left(2 r_{\mathrm{Al}}\right)$ [16], respectively. 

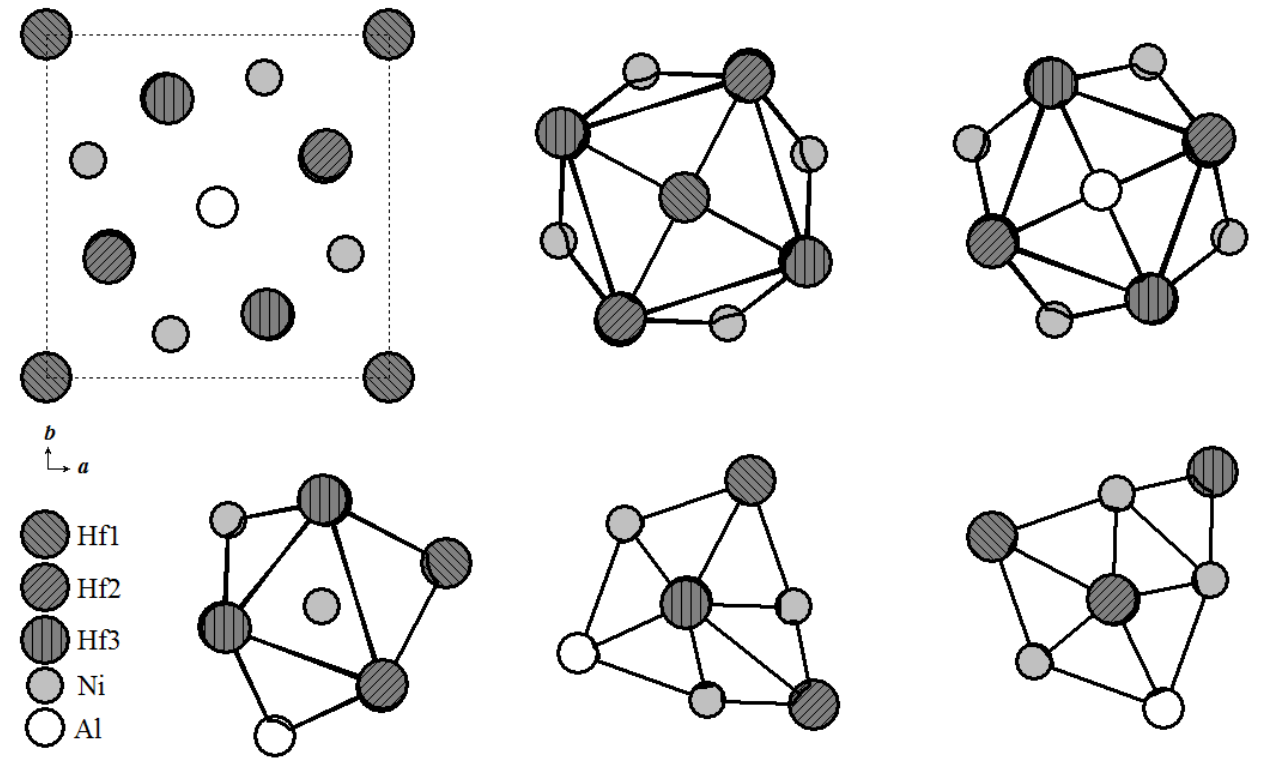

Fig. 8 Unit cell and coordination polyhedra of the atoms in the structure of $\mathrm{Hf}_{5} \mathrm{Ni}_{4} \mathrm{Al}$.

\section{Conclusion}

Six new phases, namely $\mathrm{HfAu}_{0.61} \mathrm{Al}_{1.39}, \mathrm{HfAu}_{0.84} \mathrm{Al}_{1.16}$, $\mathrm{HfAu}_{1.18} \mathrm{Al}_{0.82}, \quad \mathrm{Hf}_{1.31} \mathrm{Pt}_{4} \mathrm{Al}_{10.13}, \quad \mathrm{Hf}_{6} \mathrm{Pt}_{1.42} \mathrm{Al}_{5.58}, \quad$ and $\mathrm{Hf}_{6} \mathrm{Pd}_{1.37} \mathrm{Al}_{5.63}$, were identified, and one, $\mathrm{Hf}_{5} \mathrm{Ni}_{4} \mathrm{Al}$, was confirmed, by means of X-ray diffraction. They belong to the known structure types $\mathrm{MgNi}_{2}, \mathrm{MgZn}_{2}$, $\mathrm{Fe}_{2} \mathrm{P}, \mathrm{Sc}_{1.2} \mathrm{FeSi}_{9.8}, \mathrm{~W}_{6} \mathrm{Fe}_{7}$, and $\mathrm{Zr}_{5} \mathrm{Ni}_{4} \mathrm{Al}$, respectively. The crystal structures of the title compounds were fully investigated. The data available on the $T-M-X$ systems ( $T=\mathrm{Ti}, \mathrm{Zr}$, Hf; $M=\mathrm{Pd}$, Pt, Ag, Au; $X=\mathrm{Al}$, $\mathrm{Ga}$, In) points to the possible existence of new compounds of the above cited structure types in yet unexplored systems.

\section{References}

[1] B.Ya. Kotur, Yu.V. Verbovytsky, Prace Naukowe WSP, Chemia 8 (2003) 7-15.

[2] Yu. Verbovytsky, B. Kotur, Visn. L'viv Univ., Ser. Khim. 48 (2007) 183-186.

[3] Yu. Verbovytsky, K. Łątka, J. Alloys Compd. 438 (2007) L7-L11.

[4] W. Rieger, H. Nowotny, F. Benesovsky, Monatsh. Chem. 96 (1965) 232-241.

[5] R. Marazza, R. Ferro, G. Rambaldi, J. LessCommon Met. 39 (1975) 341-345.

[6] R. Marazza, R. Ferro, G. Rambaldi, D. Mazzone, J. Less-Common Met. 37 (1974) 285-288.

[7] E. Ganglberger, H. Nowotny, F. Benesovsky, Monatsh. Chem. 97 (1966) 829-832.

[8] R. Marazza, G. Rambaldi, R. Ferro, Atti Accad. Naz. Lincei 55 (1973) 518-521.

[9] Yu. Verbovytsky, K. Łątka, J. Alloys Compd. 431 (2007) 130-135.
[10] R. Ferro, R. Marazza, G. Rambaldi, A. Saccone, J. Less-Common Met. 40 (1975) 251-252.

[11] G. Nolze, W. Kraus, Powder Cell for Windows (Version 2.3), Federal Institute for Materials Research and Testing, Berlin, 1999.

[12] D. Schwarzenbach, Program LATCON, University of Lausanne, Switzerland, 1975.

[13] J. Rodriguez-Carvajal, T. Roisnel, FullProf.98 and WinPLOTR: New Windows 95/NT Applications for Diffraction. Commission for Powder Diffraction, International Union for Crystallography, Newsletter №20 (May-August) Summer, 1998.

[14] V.Ya. Markiv, A.I. Storozhenko, I.M. Payuta, Dopov. Akad. Nauk Ukr. RSR, Ser. A 5 (1974) 463-366.

[15] W.-H. Huang, C.-S. Lee, Intermetallics 19 (2011) 1849-1856.

[16] G.B. Bokiy, Crystal chemistry, Nauka, Moscow, 1971, 400 p. (in Russian).

[17] J. Niermann, W. Jeitschko, Z. Anorg. Allg. Chem. 630 (2004) 361-368.

[18] M.-K. Han, Y-Q. Wu, M. Kramer, B. Vatovez, F. Grandjean, G.J. Long, G.J. Miller, Inorg. Chem. 45 (2006) 10503-10519.

[19] Yu. Verbovytskyy, Thesis, Ivan Franko National University of Lviv, 2003.

[20] P. Villars (Ed.), Pearson's Handbook, Crystallographic Data for Intermetallic Phases (Desk Ed.), ASM, Materials Park, OH (1997).

[21] V.Ya. Markiv, V.V. Burnashova, Izv. Akad. Nauk SSSR, Met. 6 (1969) 181-182.

[22] A. Leineweber, H. Nitschea, V. Hlukhyy, R.-D. Hoffmann, R. Pöttgen, Intermetallics 14 (2006) 685-694. 